\title{
The Phenomenon of Common Sense and the Thinking of Alfred Schutz
}

\author{
JOAQUIN TRUJILLO \\ Authenticity LLC, Tucson, AZ 85715, USA \\ Email: jtrujillo1@me.com
}

\begin{abstract}
This article deconstructs Alfred Schutz's thinking to its ownmost (Wesen) meaning: the rendition of the phenomenon of common sense. It discerns the exposition of the meaning of common sense as the foundational movement (à $\rho \chi \eta \dot{~ \kappa ı v \eta ் \sigma \varepsilon \omega \varsigma) ~ t h a t ~}$ runs through the course of Schutz's constitutive phenomenology of the natural attitude. It predicates this thesis on Schutz's elucidation of the phenomena of the life-world

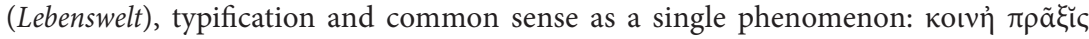
(common praxis). The analysis includes hermeneutic-phenomenological considerations. It proposes to enhance the interpretability of Schutz's thinking and its availability to the human sciences.
\end{abstract}

Key words: common sense, typification, life-world, phenomenology, sociology

\section{INTRODUCTION}

Schutz's thinking is not easy to grasp in its 'entirety' (Bierstedt 1963: 116) and often appears fragmented (Luckmann 1973: xx). It spirals through the meaning of everyday experiencing, always circling back to propel itself forward, to wrest increasingly comprehensive interpretations of the life-world (Lebenswelt). The progression of Schutz's thinking, the way he goes about exposing his matter, and as phenomenological analyses invariably go, signifies a course that is defined as much by its incompleteness as it is by its achievements, by the questions it generates as well as the hypotheses it yields. It denotes a project underway that recommends his works be studied again and again to gather a fuller understanding of the phenomena he labors to disclose-say.

This article endeavors to mitigate the challenges endemic to understanding Schutz by distilling his thinking to its ownmost (Wesen) meaning: the rendition of the phenomenon of common sense. It discerns the exposition of the meaning of common sense as the foun-

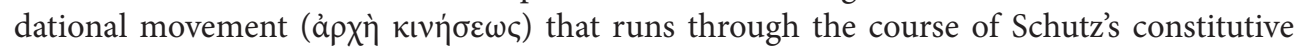
phenomenology of the natural attitude. It predicates this thesis on Schutz's elucidation of the phenomena of the life-world, typification and common sense as a single phenomenon:

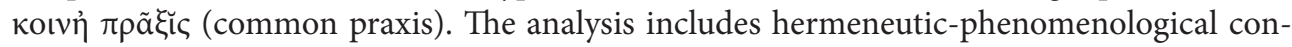
siderations. It proposes to enhance the interpretability of Schutz's thinking and its availability to the human sciences. The project's aspirations are not unlike those Gros pursues in his analysis of the 'mundane' in Schutz's phenomenology (2017), but are more radical than those 
implied in Embree's deconstruction of Schutz's thinking into a hierarchy where the exhibition of 'common-sense thinking' is largely confined to the 'bottom level' (2008: 143). This study is most closely aligned with Natanson's scholarship (1962; 1970; 1986; 1998). Perhaps no other researcher, including Gurwitsch (1966) and Luckmann (1973), has thoroughly coincided the rendition of the phenomenon of common sense ('common sense reality') with the central motif of Schutz's phenomenology than Natanson has. This study diverges from Natanson's work in the extent to which it unearths that correspondence and the equivalency it contends Schutz denotes among the phenomena of common sense, typification and the life-world.

\section{THE LIFE-WORLD}

Schutz's hermeneutical point of 'reference and departure' is Husserl's transcendental phenomenology (Gurwitsch 1966; Breda 1962). Schutz's radicalizes the sociology of Verstehen - the 'experiential form in which common-sense thinking takes cognizance of the social cultural world' (Schutz 1954: 264) - by situating the interpretation of social phenomena within Husserl's transcendental phenomenological rendition of consciousness as intentionality. Intentionality, understood transcendental phenomenologically, and by Schutz, is consciousness rendered as 'consciousness of, or, more exactly, the correlation between (and irrevocable unity of) the experiencing-of-phenomena (vónбıৎ) and the phenomena-experienced (voć $\mu \alpha$ ). It is the total transformation (unfurling, evolution) of cogitations that are postulated to constitute consciousness. It is subjectivity, or transcendence, and, thought more radically, the life-world itself insofar as the life-world is its experience, or more precisely, the totality of human experiencing.

The understanding of subjectivity as the life-world is embedded within the transcen-

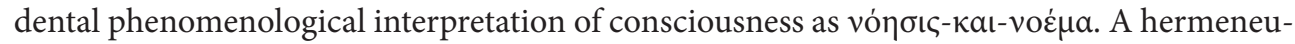
tic-phenomenological reading of Schutz (and Husserl) yields the same thesis. The description of intentionality as 'consciousness of', the notion of consciousness as defined by its transcendent, is akin to the hermeneutic-phenomenological exposition of human being as the being-of-t/here, or Dasein (also, transcendence). The perspectives are commensurate and allow for some measure of migration of observations and theses between them. They both define subjectivity as transcendence, or, more precisely, transcending, equate transcendence with the life-world, and in their own ways distinguish the life-world as a 'wherein' and 'process of becoming' (coming to pass, happening). The life-world (subjectivity) rendered as transcendence, and regardless of the perspective, is the 'world' wherein 'we find ourselves' and come to pass as 'at every moment of our life'. It is the becoming of the world 'exactly as it presents itself to us in our everyday experience, 'indefinitely extended in space and time', comprising 'natural material things', 'cultural objects', and 'animal creatures as well as fellow human beings, to whom we stand in manifold relations' (Gurwitsch 1966: xi). It is the 'singular' t/here (world) each and every Dasein together is (transcends to) and the happening ('disclosure') of 'every being of beings in the whole' (das Seiende im Ganzen) (Kalary, Schalow 2011: 201-202).

Schutz's employment of the phenomenological reduction ( $\dot{\varepsilon} \pi 0 \chi \eta \dot{)})$ is intrinsic to his interpretation of the life-world. The phenomenological reduction is transcendental phenomenology's initial methodological step and fundamental to Schutz's endeavor to specify the constitution of human experiencing. It is the open, resolute effort to suspend the general thesis of the natural attitude, or the presuppositional (mindless) commitment to (belief in) the meanings that constitute the life-world. The natural attitude is the prereflective comportment to take the experiencing of the life-world for granted and the phenomenological reduction is the effort 
to put the disposition in abeyance and free the thinker of its assumptions and predications. Gurwitsch calls the life-world 'the world of the natural attitude' (Welt der natürlichen Einstellung) (1966: xii), and Schutz equates it with the 'social world', 'social reality', the 'world of daily life', and the 'common-sense world' (1953; 1955; 1944; 1943; 1945; Gurwitsch 1966). The distillate of the reduction, according to Schutz, is 'the pure life of consciousness'. It is the factical ('objective') world endured and fashioned 'in' and 'through' intentionality (1962: 123). Thought hermeneutic-phenomenologically, the reduction unleashes the thinker's power to exhibit subjectivity, the matrix of unfolding experiences (cogitations, intentions) that constitute the individual discerned as an event, as transcendence. It beckons, hence, a minding of intentionality's ontological dimensions, of human being (Dasein) and being (Sein). The 'to be' of subjectivity summons to be thought when the thinker inabides (Inständig) the originary equivalency of intentionality and the life-world, and cannot be displaced by the غ̇ं⿰ớ. It cannot be nullified by any professed 'suspension' of 'belief in the reality of the world as a device to overcome the natural attitude' (Schutz 1945: 550). The human 'to be' is impervious to the phenomenological reduction no matter how hard one may strive to 'abstain from belief in the being of this world', as Schutz's contends, and direct one's view 'exclusively' to 'consciousness' (1962: 123). It can only be nullified by death.

The life-world, as Schutz interprets it, is 'paramount reality' (1945; 1955). It is the knowable and taken-for-granted world persons together are notwithstanding their unique attributes or perspectives, and the world that is factically intersubjective (Schutz 1945; 1951b). Subjectivities within the life-world are conjoined inceptually through interconnections of actual experience' (Schutz 1966: 52) and, more primordially, the meaning of 'is', including the 'isness' of togetherness (Trujillo 2018a, b). The life-world is the reality persons commensurately endure and one dominated by 'eminently practical interests' rather than 'theoretical' ones (Schutz 1945: 534). It is the 'public world' wherein individuals 'pursue' all their 'goals', 'always' take their 'bearings' (Gurwitsch 1966: xii), and the 'scene' they are compelled to 'dominate' and 'change' to realize their purposes (Schutz 1945: 534). It is also 'from the outset a sociocultural world'. The 'greater portion' of experiencing that constitutes the life-world is 'socially derived' and 'socially approved'. Only a 'small fraction' originates biographically (Schutz 1955: 193), and it is also socially influenced.

\section{THE PHENOMENON OF TYPIFICATION}

The life-world that Schutz reveals is essentially a typical one. It is overwhelmingly defined by typifications. It is the experiencing of phenomena as phenomena generally have been experienced. It is a singular flux of meanings constituted through a 'passive synthesis' of the present and the present perfect, of the 'is' and 'has been' (Schutz 1955: 145; 1950). Typifications are 'open horizons of anticipated similar experiences' (Schutz 1953: 5). They are 'ways of life', or 'efficient recipes for the use of typical means for bringing about typical ends in typical situations' (Schutz 1953: 10). Their basic features include commonness, anonymity, practicality, facility and taken-for-grantedness. Typifications are ordinary. They are socially defined or influenced. Their presence in consciousness is ubiquitous. The ones associated with an in-group are universally available to constituents. Typifications are functional. They are cognitive archetypes that commonly supersede the 'thought objects' of 'private experience' (Schutz 1953: 8), conceptual models of knowing, doing and saying that belong to no one and everyone. Typifications are generated by the production of human living. Their genesis is associated with the factical need of persons to live and work among others in a world dominated by 
pragmatic interests. They are 'graduated knowledge of relevant elements' (Schutz 1944: 500) and enable the comprehension and management of daily life. Typifications are prepredicated. They are automatically accepted as the way things are and should be as long as their utility goes unchallenged or 'counterevidence is offered' (Schutz 1944; 1955: 174; 1953: 3).

Schutz locates typifications within the 'stock of knowledge at hand' (1955). The stock of knowledge at hand is the index and repository of typical experiences sedimented in consciousness. It comprises lived knowledge and knowledge immediately available to intentionality, and is largely populated through 'the vocabulary and syntax of everyday language'. Everyday language is the vernacular. It consists of the locutions of the world of working. Schutz calls the vernacular 'the typifying medium par excellence by which socially derived knowledge is transmitted' (1953: 9-10). He further describes it as 'a treasure house of preconstitued types and characteristics, each of them carrying along an open horizon of unexplored typical contents', and separately adds: by naming an experienced object, we are relating it by its typicality to preexperienced things of similar typical structure, and we accept its open horizon referring to future experiences of the same type, which are therefore capable of being given the same name' (1950: 393).

Schutz interpretation of language implies that it is more than a means of classifying, transmitting and storing types, however. It is suggestive of the deeper relation hermeneutic-phenomenology posits between language, intentionality, and Dasein, as denoted by the theses, 'Human being is language' (Kovacs 2013: 129) and 'We - human beings - are a conversation' (Heidegger 2000: 55-56). He comes near to this meaning of language when he writes that language 'pertains as communication $\kappa a \tau$ ' '̇ं and, therefore, obstinately resists serving as a vehicle for meanings which transcend its own presuppositions' (1945: 555). Not only is everyday language the author of typical knowledge, it drives the production, recapitulation, and accretion of typifications in consciousness. At the same time it typically reveals, constitutes, and specifies the meaning of phenomena, including the life-world, 'self', and 'other', it fashions the typical content of experiencing and frees subjectivity to develop its natural conception of the world. Moreover, it is continuous with them. Everyday language, the stock of knowledge at hand, and the general thesis are indivisible. They are conjoined dimensions of subjectivity.

The phenomenon of typification is the universal, transformative process of typifying and the unfolding totality of typical experiencing. It is the life-world as it is constituted, hence, experienced. It is the world of daily life. Typifications define everyday reality, the projects persons design and live in the natural attitude, and the 'cultural pattern of group life' (Schutz 1944: 499-500). They include, to borrow from Goffman, patent 'rules' for knowing, doing and saying (1966: 194) and, as Berger and Luckmann observe, 'collectively relevant' meaning-artifacts that 'hang together' as social structure (1967: 63). They are anonymous, taken-for-granted meanings that compose 'the scene of social relationships and actions', as Gurwitsch remarks (1966: 7), and, although always intersubjectively generated, are also always, as Schutz repeatedly notes, biographically influenced (1953; 1955; 1951a); biographical experiences are also for the most part typically structured and interpreted regardless of their genesis. Typifications are endemic to everyday language, social action and the natural attitude. They imbue intentionality with public meaning, constitute the ordinary (lived, taken-for-granted) comprehension of the life-world, and shape the articulation of individuality. They constitute the subjectivity of the 'wide-awake' person living in and acting upon the world of daily life among his fellow-persons (Schutz 1945; 1953). 


\section{THE PHENOMENON OF COMMON SENSE}

Schutz's interpretation of the life-world and the phenomenon of typification projects-open (transports the thinker into) the ownmost meaning of his constitutive phenomenology of the natural attitude: the rendition of the phenomenon of common sense. Schutz's deliberate, backand-forth disclosure of the life-world and phenomenon of typification reveals the exhibition

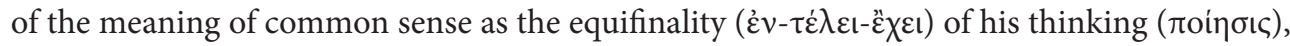
as the fundamental movement harbored within his phenomenology of the world of daily life. His illumination of the typical constitution of the life-world, the equivalency he unearths between the world of daily life and the phenomenon of typification, is called forth (propelled forward) by the disclosure of the meaning of common sense. Schutz comes to an understanding of the phenomenon of common sense by way of his investigation of the life-world and phenomenon of typification. The moments are penultimate to the transitional conclusion that the phenomenon of common sense is not a derivative of the life-world and phenomenon of typification, but, rather, commensurate with them. Not only does common sense see, act and interpret the life-world through the typifications implicit to the natural attitude, as $\mathrm{Na}$ tanson asserts (1962: xxvii), but, thought more radically, the phenomenon of common sense is the life-world and the phenomenon of typification. Each in its own way means paramount reality. Each denotes the world of daily life shared by wide-awake persons enduring the same system of typifications (i.e. 'finite province of meaning') (Schutz 1955).

Definitive steps toward discerning the equivalency among the phenomena of the lifeworld, typification and common sense are witnessed in Schutz's later writings when he distinguishes the 'life-world' as the 'common-sense world' (1953; 1954; 1955; Gurwitsch 1966), 'typifications' as 'common-sense constructs', and everyday thinking as 'common-sense thinking' (1955; 1953). The movement is also implied in his description of the vernacular as the typifying medium par excellence, which would indicate everyday language as 'common-sense language'. The course comes to its denouement when Schutz discerns 'common sense' as 'common-sense praxis' (1955). There he appears to be thinking the meaning of common sense as $\kappa o เ v \eta \dot{~} \pi \rho \tilde{a} \xi \varsigma$, a play on pre-Socratic words that do not occur together in original (pre-philosophical) Greek. The escamotage makes the 'sense' in 'common-sense praxis' superfluous,

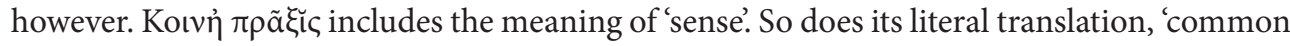
praxis', when thought vis-à-vis the meaning of the source-language words. Read together,

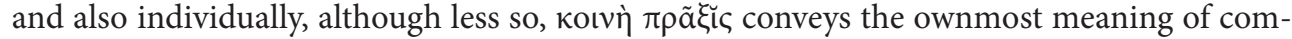
mon sense, including its equivalency with the life-world and phenomenon of typification. It is the world typically constituted and experienced. It is the world of the natural attitude.

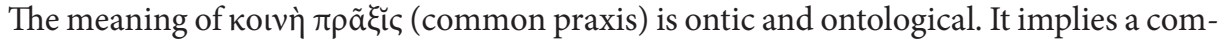
prehension of beings individuated as discrete beings and as beings in relation to their being and situatedness within beings in the whole. Kotvi denotes the ontic characteristics of commonality, anonymity, taken-for-grantedness, as well as public, which indicates in-groupness, social genesis, social knowledge, social approval, and the collective understanding that binds constituents into a group. It also signifies the pre-philosophical 'with' ( $\mu \varepsilon \tau \breve{\alpha})$, or being-with (Mitsein), which also connotes being-with-others (Mitdasein). Being-with is an existential (ontological structure) of Dasein. It 'is the foundation of community and of interpersonal rela-

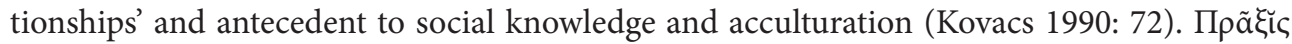
means a making use 'in one's daily preoccupation'. It corresponds with a prepredicated (taken-for-granted, lived) thesis (understanding) grounded in $\pi \rho \dot{\alpha} \gamma \mu \alpha \tau \alpha$, or things encountered in their thingness (being) and relation to the human 'to be' (Richardson 1967: 53). Taken as 


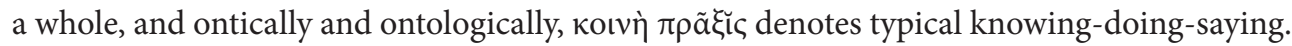
It means Verstehen, mundane experiencing, or everyday transcending.

Koเvì $\pi \rho \tilde{a} \xi \breve{\zeta}$ f further signifies the mutual immanence of language and the world of daily life. Being-with is the originary possibility of Dasein's disclosing-saying power, of $\lambda$ ó $\gamma$ oc. It is the abground (Abgrund) of language. It is the time-space wherein words are freed to reveal and constitute meaning. Being-with enowns (ereignet) the potentiality of distinct Daseins to come

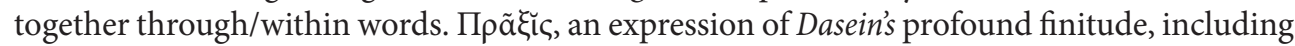
its dependence on beings to be, also belongs to $\lambda$ ó $\gamma$ oc. It is a derivative of Sorge (concern) and intrinsically bound to (an intimate expression of) the practical concerns that overshadow

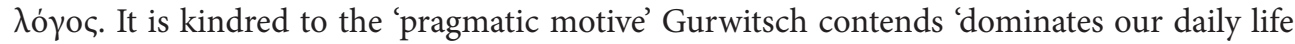

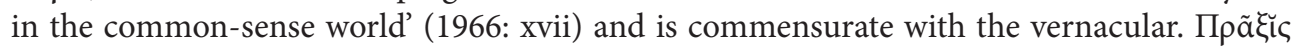
and the vernacular, the locations of the world of working, innately belong to each other. They constitute a single mode of comportment with beings and beings in the whole.

Schutz's arrives at a culminating moment (gathering point) in his thinking when he interprets the meaning of common sense as кoเvì $\pi \rho \tilde{a} \xi \check{\iota}$. Not only does the course of Schutz's phenomenology run through investigations of the life-world and the phenomenon of typification to arrive at the meaning of common sense, its innermost dynamism announces itself as the rendition of the phenomenon of common sense from start to finish. Schutz writings, particularly the successive correspondences among the phenomena of the life-world, typification and common sense he posits, imply an essential movedness. They suggest themselves as unfolding parts of his original program to clarify the meaning of Verstehen, which in The Phenomenology of the Social World, first published in 1932, he defines as 'understanding' (1967: 12), but then later equates to common-sense experiencing (1954). They appear as steps along the 'laborious philosophical journey' he assumed to deduce the 'meaning-structure of the social world...from the most primitive and general characteristics of consciousness' (Schutz 1967: 12). They show themselves as gradations of the unearthing of the ownmost meaning of common sense.

\section{CONCLUDING REMARKS}

Luckmann describes the 'final summing up' of Schutz's 'thought and work' as 'the systematic description of the common-sense world as social reality' (1973: xx). Gurwitsch implies the same thesis in his analysis of 'Schutz's conception of the common-sense world as social reality' (1966: xv). Natanson gives an alternate (but not unrelated) interpretation that corresponds more closely with this analysis. He writes: 'the understanding of the paramount reality of common-sense life is the clue to the understanding of the work of Alfred Schutz' (1962: xxv). A renewed reading of Schutz that includes hermeneutic-phenomenological considerations yields a more radical thesis. It suggests that the phenomenon of common sense is paramount reality. It is the life-world, and, hence, more inclusive than social reality. It is the phenomenon of typification, including the typical interpretation and articulation of biographically sourced experiences. It is koเvì $\pi \rho \tilde{a} \xi \breve{\zeta}$, the world of working. The analysis further suggests that Schutz arrives at his conception of human reality by way of the rendition of the phenomenon of common sense. Schutz's elucidation of the meaning of common sense, the 'architectonic of common sense' he offers, as Natanson describes it (1986: 44), is the foundational movement sheltered within his constitutive phenomenology of the natural attitude. It is the ownmost meaning and equifinality of his thinking, the gathering movedness of his reflections about the life-world. 
We recast the ambiguities and limitations of Schutz's works as phenomenological byproducts of a hermeneutically consistent interrogation of the life-world when we reduce his thinking to its ownmost meaning. The project allows for a more exact and efficient reading of Schutz by attenuating the need to decipher clues, as Natanson implies, to unravel his understanding of the world of daily life. It delineates a navigational line by which to follow Schutz's thought and works and avoid losing one's way among the 'twists and turns' and 'starts and stops' characteristic of his phenomenological program. It reduces the risk of losing sight of Schutz's course, abandoning attempts to comprehend the meaning of the phenomena he labors to disclose-say, and relegating his works to footnotes, short lectures and bibliographic entries. It facilitates the effort to project-open through Schutz to increasingly radical conceptions of the life-world.

This project further proposes to increase the availability of Schutz's phenomenology to the human sciences. Accessibility is correlated to interpretability. The two go hand-in-hand. Reducing Schutz's phenomenology to an investigation of the phenomenon of common sense rather than the exposition of common-sense reality as social reality extends the practicality of his hermeneutics. It increases access to Schutz by giving way to a more incisive reading of his works and relating his propositional assertions more directly to the experiencing of the everyday person, or the 'man on the street', as Schutz sometimes calls him (1946). When Schutz's theses about common sense are clarified hermeneutic-phenomenologically, it relieves one of the obligation to contend with abstruse, even enigmatic, notions of reality (e.g. common-sense reality, social reality and the life-world) and surmount their associated metaphysical assumptions to systematically assimilate Schutz's interpretation of typical knowing-doing-saying. It also differentiates the ontic and ontological standpoints implied by Schutz's interpretation of common sense and thereby increases the heuristic power to employ either perspective (or both) in research or analysis. Disclosing the fundamental movedness of Schutz's thinking, reading his works within that context, interpreting his thinking in the light of its equifinality, augments the specificity and concreteness of his constitutive phenomenology of the natural attitude and opens the way for its increased application in the psychological and social sciences.

Received 5 May 2021

Accepted 2 July 2021

\section{References}

1. Berger, P. L.; Luckmann, T. 1967. The Social Construction of Reality: A Treatise in the Sociology of Knowledge. New York: Doubleday.

2. Bierstedt, R. 1963. 'Review: The Common Sense World of Alfred Schutz', Social Research 30(1): 116-121.

3. Breda, H. L. Van. 1962. 'Preface', in Collected Papers I: The Problem of Social Reality, ed. M. Natanson. The Hague: Martinus Nijhoff, vi-xiii.

4. Embree, L. 2008. 'The Nature and Role of Phenomenological Psychology in Alfred Schutz, Journal of Phenomenological Psychology 39(2): 141-150.

5. Goffman, E. 1966. Behavior in Public Places: Notes on the Social Organization of Gatherings. New York: The Free Press.

6. Gros, A. E. 2017. 'Alfred Schutz on Phenomenological Psychology and Transcendental Phenomenology', Journal of Phenomenological Psychology 48(2): 214-239.

7. Gurwitsch, A. 1966. 'Introduction', in Collected Papers III: Studies in Phenomenological Philosophy, ed. I. Schutz. The Hague: Martinus Nijhoff, xi-xxxi.

8. Heidegger, M. 2000. Elucidations of Hölderlin's Poetry, ed. K. Hoeller. Amherst: Humanity Books, 51-65.

9. Kalary, T; Schalow, F. 2011. 'Attunement, Discourse, and the Onefold of Hermeneutic Phenomenology: Recent Heidegger-Literature and a New Translation of His Work in Critical Perspective', Heidegger Studies 27: 199-210. 
10. Kovacs, G. 1990. The Question of God in Heidegger's Phenomenology. Evanston: Northwestern University Press.

11. Kovacs, G. 2013. 'Heidegger's Insight Into the History of Language', Heidegger Studies 29: 121-132.

12. Luckmann, T. 1973. 'Preface', in The Structures of the Life-World. Vol. 1. Trans. R. M. Zaner and H. Tristram Engelhardt, Jr. Evanston: Northwestern University Press.

13. Natanson, M. 1962. 'Introduction', in Collected Papers I: The Problem of Social Reality, ed. M. Natanson. The Hague: Martinus Nijhoff, xxv-xlvii.

14. Natanson, M. 1970. 'Phenomenology and Typification: A Study in the Philosophy of Alfred Schutz', Social Research 37(1): 1-22.

15. Natanson, M. 1986. Anonymity: A Study in the Philosophy of Alfred Schutz. Bloomington: Indiana University Press.

16. Natanson, M. 1998. 'Alfred Schutz: Philosopher and Social Scientist', Human Studies 21: 1-12.

17. Richardson, W. J. 1967. Heidegger: Through Phenomenology to Thought. The Hague: Martinus Nijhoff.

18. Schutz, A. 1943. 'The Problem of Rationality in the Social World', Economica 10(38): 130-149.

19. Schutz, A. 1944. 'The Stranger: An Essay in Social Psychology', American Journal of Sociology 49(6): 499-507.

20. Schutz, A. 1945. 'On Multiple Realities', Philosophy and Phenomenological Research 5(4): 533-576.

21. Schutz, A. 1946. 'The Well-Informed Citizen: An Essay on the Social Distribution of Knowledge', Social Research 13(4): 463-478.

22. Schutz, A. 1950. 'Language, Language Disturbances, and the Texture of Consciousness', Social Research 17(3): 365-394.

23. Schutz A. 1951a. 'Choosing Among Projects of Action', Philosophy and Phenomenological Research 12(2): 161-184.

24. Schutz, A. 1951b. 'Making Music Together: A Study in Social Relationship', Social Research 18(1): 76-97.

25. Schutz, A. 1953. 'Common-Sense and Scientific Interpretation of Human Action', Philosophy and Phenomenological Research 14(1): 1-38.

26. Schutz, A. 1954. 'Concept and Theory Formation in the Social Sciences', The Journal of Philosophy 51(9): 257-273.

27. Schutz, A. 1955. 'Symbol, Reality and Society', in Symbols and Society: Fourteenth Symposium on Science, Philosophy, and Religion, eds. L. Bryson, L. Finkelstein, H. Hoagland, R. M. MacIver. New York: Harper and Brothers, 135-203.

28. Schutz, A. 1962. 'Phenomenology and the Social Sciences', in Alfred Schutz Collected Papers I. The Problem of Social Reality, ed. M. Natanson. The Hague: Martinus Nijhoff, 118-139.

29. Schutz, A. 1966. 'The Problem of Transcendental Intersubjectivity in Husserl', in Collected Papers III: Studies in Phenomenological Philosophy, ed. I. Schutz. The Hague: Martinus Nijhoff, 51-83.

30. Schutz, A. 1967. The Phenomenology of the Social World. Trans. T. G. Walsh and F. Lehnert. Evanston: Northwest University Press.

31. Trujillo, J. 2018a. 'Alienation and the Sociology of Alfred Schutz', Bulletin d'Analyse Phénoménologique 14(8): $1-33$.

32. Trujillo, J. 2018b. 'Intersubjectivity and the Sociology of Alfred Schutz', Bulletin d'Analyse Phénoménologique 14(7): $1-30$. 
JOAQUIN TRUJILLO

\title{
Sveiko proto fenomenas ir Alfredo Schutzo mąstymas
}

\begin{abstract}
Santrauka
Straipsnis dekonstruoja Alfredo Schutzo mąstymą iki jo esmiškiausios (Wesen) reikšmès - sveiko proto fenomeno interpretacijos. Straipsnio autorius akcentuoja, kad sveiko

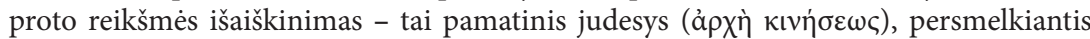
visą A. Schutzo natūralios nuostatos konstitutyvinès fenomenologijos teoriją. Ši tezè argumentuojama A. Schutzo pateiktu išaiškinimu, kad gyvenamojo pasaulio (Lebenswelt), tipizacijos ir sveiko proto fenomenai iš tikrųjų yra vienas reiškinys - bendroji praktika

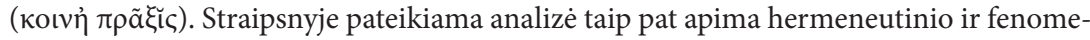
nologinio pobūdžio svarstymus, siūlydama išplèsti A. Schutzo mąstymo interpretacijos galimybes ir jo pritaikomumą humanitariniams mokslams.
\end{abstract}

Raktažodžiai: sveikas protas, tipizacija, gyvenamasis pasaulis, fenomenologija, sociologija 